Interdisciplinary Contexts of Special Pedagogy
NUMBER 27/2019

\title{
Towards a radical life. Social and political threads of Helen Keller's activities
}

\begin{abstract}
Sabina Pawlik, Towards a radical life. Social and political threads of Helen Keller's activities. Interdisciplinary Contexts of Special Pedagogy, no. 27, Poznań 2019. Pp. 151-161. Adam Mickiewicz University Press. ISSN 2300-391X. e-ISSN 2658-283X. DOI: https:// doi.org/10.14746/ikps.2019.27.07

Biographies of people with disabilities emphasising on their humanity and the value of this very special human experience may lead to questioning common assumptions about disability and people suffering from it. One of the best known historical figures among the people with disabilities was Hellen Keller, a deaf-blind American writer, educator and social activist. The article contains an attempt to challenge the myth of Keller as a "miracle child" by presenting her rich life and the most prominent aspects of her social and political activity.
\end{abstract}

KEY WORDS: disability, biographies, disability history, socialism, feminism

We must make you realise that the world you love, the world that excites and entertains you, would not exist if there were no defective genes... and it will cease to exist if you continue to seek to remove disabled people from the future of humanity.

Nabil Shaban ${ }^{1}$

${ }^{1}$ The polemic titled Body Fascism and Genetic Cleansing) against the "genetic cleansing, written by Nabil Shaban in 2000 for the BBC programme titled Heaven and Earth Show, <http://www.geocities.ws/jinghiz/genetic_cleansing.html> [29.05.2019]. 


\section{Biographies in disability history}

The opening quote comes from a polemic titled "Body Fascism and Genetic Cleansing", written by Nabil Shaban in 2000 for the BBC programme titled Heaven and Earth Show. The author, in his polemics that "We, so-called disabled and defective people have brought you Beethoven, Toulouse le Trec, Byron, Walter Scott, Stevie Wonder, Virginia Woolf, Woody Guthrie, Stephen Hawking, Julius Caesar, Attila the Hun, Ivarr the Boneless, Nelson...Roosevelt, JFK, Stephen Hawking"2. By revealing the known historical narratives, the author opposes the conventional ways of presenting and interpreting the phenomenon of disability, placing his contribution in the change of the social approach towards human diversity ${ }^{3}$.

The biographies of persons with disabilities, emphasising on their humanity, and the value of this particular human experience, may lead to questioning the universally accepted premises regarding disability, and persons with disabilities. They are an important aspect of the identity of the members of this community, however, they were (are) marginalised and forgotten to a large degree. Through the years, few wished to identify with them, and persons with disabilities were socially invisible. Bringing back the memory of these persons is a form of regaining own history, also by the entire society ${ }^{4}$, which shows the gradual social destigmatisation of the phenomenon.

One of the best known persons with disabilities in history is the deaf-blind American writer, pedagogue, and social activist Hellen Keller. Despite the fact, that she is without a doubt known world-

2 N. Shaban, Body Fascism and Genetic Cleansing (a television polemical script by Nabil Shaban), <http://www.geocities.ws/jinghiz/genetic_cleansing.htmlcyt> [29.05.2019], quote after: K. Ojrzyńska, Nabila Shabana dialog z kultura sprawna, „Tekstualia" 2017 no 4(51), p. 166.

${ }^{3}$ K. Ojrzyńska, Nabila Shabana, op. cit., p. 166.

${ }^{4}$ K. Ojrzyńska, O leczeniu społecznej amnezji: Akcja T4 w kulturze wspótczesnej, [in:] Niepetnosprawność w teatrze i performansie, (ed.) E. Godlewska-Byliniak, Fundacja Teatr 21, Warszawa 2018, p. 286. 
wide, one of the authors of her biography, Kim E. Nielsen notes ${ }^{5}$, that the her story often begins and ends when Anne Sullivan, placing the hand of her student under a current of water, spells the letters of the word water into her other hand, causing the child, which was previously beyond the sphere of language, could miraculously understand its essence. It was a "miracle" which would forever define the image of Helen Keller6. "My teacher placed my hand under the spout. As the cool stream gushed over one hand she spelled into the other the word water (...) Suddenly I felt a misty consciousness as of something forgotten (...) and somehow the mystery of language was revealed to me (...) I left the well-house eager to learn"7 - writes the author, back then of 23 years of age.

Helen Keller, appearing at the mass meetings of striking workers, seems to be an entirely different version. The iconography, that shapes our cultural memories, mostly omits the involvement of Keller in the political life, particularly her interest in radical socialism and the critique of capitalism, while the author herself is mostly remembered as a little, deaf-blind girl, a "miracle child", which managed to overcome adversities. Few know that behind this image, a "flesh and blood" woman stands, a writer, a radical activist, a suffragist, and a socialist ${ }^{8}$.

Her political views were unwelcome even during her life. The author mentions the fact in her letter to senator Robert La Follete, where she reproaches him, that since she went beyond the sole involvement for blind persons, and publicly announced her political views, seeing capitalism as the cause of all harm and social inequalities, he stopped treating her with seriousness and respect ${ }^{9}$.

${ }^{5}$ K.E. Nielsen, Helen Keller and the Politics of Civic Fitness, [in:] The New Disability History: American Perspectives, (eds.) P.K. Longmore, L. Umansky, New York University Press, New York - London 2001, p. 268.

${ }^{6}$ L. Crow, Helen Keller: Rethinking the Problematic Icon, "Disability \& Society" 2000, no 6(15), DOI: 10.1080/713662010, p. 1.

${ }^{7}$ H. Keller, Historia mojego życia, Czytelnik, Warszawa 1978, p. 28.

${ }^{8}$ L. Crow, op. cit., p. 1.

${ }^{9}$ H. Keller, I Am For You, [in]: Helen Keller. Selected writing, (ed.) K.E. Nielsen, New York University Press, New York - London 2005, p. 71. 


\section{The brief biography of Keller read anew}

Helen Keller was born in 1880 in Tuscumbia, Alabama, as the first child of captain Arthur Keller and his second wife Kate. At 19 months of age, after suffering a condition, Hellen Keller lost sight and hearing. The family had difficulties in communicating with the little Helen, and the child would become increasingly "wild and destructive"10. At the age of 7 Helen was visited by Anne Sullivan, who had become her teacher, mentor and a friend; the women will become inseparable up until Sullivan's death in 1937. At 18, Helen passes entry exams to Radcliffe, the most prestigious college for women of the time. She graduates it with honours in $1904{ }^{11}$.

In 1903 Keller publishes an autobiography titled "The Story of My Life", where she describes her early years. The events described by the author will weigh down on the way she will be perceived not only by her contemporaries, but also by the subsequent generations of "The Story" readers.

Back in her student years, Keller was introduced to the ideology of socialism by the lecturer and journalist John Macy (who will later marry Anne Sullivan). In this ideology, she finds the reflection of her own fight for equality, and the socialism would become her life path, and the source of her activism ${ }^{12}$. In 1909 she joins the Socialist Party of America, and in 1920, she writes an essay titled "How I Became A Socialist"13. In her later activities, Keller fights for voting rights and the equality of women, she also fights for the rights of the working class, and is an advocate of birth control. She severely criticises the war, seeing it as an enterprise designed solely for the profit of the wealthiest parts of the society. Therefore, she calls the work-

10 L. Crow, op. cit., p. 4.

11 K.E. Nielsen, The Radical Lives of Helen Keller, New York University Press, New York - London 2009, pp. XI-XII.

12 L. Crow, op. cit., p. 30.

${ }^{13}$ H. Keller, How I Became A Socialist, <https://www.disabilitymuseum.org/ dhm/lib/detail.html?id=2447>. 
ers to rebel against it ${ }^{14}$. Until the end of her days, she would be faithful to her views, fighting for economic justice, and social equality. She would write essays, conduct social activity, meet with veterans and travel around the world (i.a. in 1948 she visited the Japanese Nagasaki and Hiroshima, she also travelled to India, Africa, Australia, Syria, Lebanon, and Israel) ${ }^{15}$. In the 1960s, after suffering from a stroke, she would gradually withdraw from public life. Helen Keller died on 1 June 1968, 32 years after her teacher and friend Anne Sullivan.

\section{The selected themes of Keller's social and political activity}

\section{Keller's attitude towards disability}

Helen Keller's attitude towards the phenomenon disability was indivisibly tied to her social and political views. Long before the definition of the social model of disability, Keller would promote her views, stating, that disability is mostly a result of the cultural, legal, and social determinants, and is closely tied to the social class ${ }^{16}$, and saw the industrialisation and poverty as its primary causes. In her article titled "Modern Woman" from 1912, she wrote that: "the blind man, however poignantly his individual suffering appeals to our hearts, is not a single, separate person whose problem can be solved by itself, but a symptom of social maladjustment"17.

The author vividly spoke out against the social isolation with persons with disabilities. During her trip to Israel (1952), when the hosts showed Keller a village for persons with disabilities, she violently protested against segregation practices, attempting to persuade the organisers to shut it down ${ }^{18}$.

${ }^{14}$ K.E. Nielsen, Helen Keller and the Politics..., op. cit., p. 268.

15 K.E. Nielsen, The Radical..., op. cit., pp. XI-XII.

16 L. Crow, op. cit., p. 12.

17 H. Keller, The Modern Woman, <https://www.disabilitymuseum.org/dhm/ lib/detail.html?id=2449> [29.05.2019].

18 L. Crow, op. cit., p. 12. 
Keller expressed her objections regarding treating organisations that work for blind persons, as charity institutions. She demanded not only high financing for the blind, regarding their education (however, obviously, she considered education to be essential), but also, the creation of sufficient conditions, so that these persons could be self-dependent and socially useful: "Blind graduates of (...) schools have said to me in the bitterness of disappointed hopes and ambitions, it would have been better to leave us in ignorance than to enlighten and cultivate our minds only to plunge us into a double darkness. What boots it that we have spent our youth in kindergartens, museums, libraries, and music-rooms if we pass from those pleasant halls to sit with idle hands (...) The time has come when strong and efficient measures should be taken in America to give the blind an opportunity to become self-supporting (...) it is a disgrace that any man should be forced to sit in idleness" 19 .

\section{Feminism}

After many years following Keller's death, the contemporary works dedicated to her, try to tackle the stereotypical, sentimental image of a brave, deaf-blind girl, who, through hard work, managed to overcome her limitation. The works attempt to rediscover the real message of the author and its significance to the broader understanding of the participation of women with disabilities in history and politics ${ }^{20}$.

The grounds for Keller's feminism, was the belief in the necessity of striving for justice and social equality ${ }^{21}$. In her public activity, she highlighted that women's rights are a bigger part of an issue, that is universal social justice ${ }^{22}$. She also believed, that the giving

${ }^{19}$ H. Keller, What The Blind Can Do, <https://www.disabilitymuseum.org/ $\mathrm{dhm} /$ lib/ detail.html?id=2502\&page $=2>$ [29.05.2019].

20 R. Garland-Thomson, Feminist Disability Studies, "Signs" 2005 no 30(2), p. 1560, DOI: $10.1086 / 423352$.

${ }^{21}$ L. Crow, op. cit., p. 12.

22 K.E. Nielsen, Introduction to Keller's letter The Enfranchisement of Woman, [in:] Helen Keller: Selected..., op. cit., p. 51. 
women voting rights will contribute to the victory of socialism, that is why she eagerly supported the suffragist movement in the United States and in Great Britain. In her letter to the British activists for women's voting rights, she wrote: "The enfranchisement of women is a part of the vast movement to enfranchise all mankind (...) Have your men with their millions of votes freed themselves from this injustice?"23.

In a letter to Eleanor Roosevelt, with which she felt a specific bond, due to their common frustrations resulting from the limitations imposed on women, and their mutual vision of a better world, she wrote: "You inspire other women with confidence and in life. You show them how through rightly directed intelligence and willpower can evolve higher capabiltities and raise the average of human accomplishment (...) Sincerely I admire you for the courage with which you have declared yourself on the side of underprivileged and industrially oppressed women ${ }^{24 \prime}$.

In her views, Keller would promote the necessity of birth control, she was also an advocate of eugenics. In 1915, she publicly supported the controversial movement of Margaret Sangerr ${ }^{25}$ presenting the socio-economical and eugenic premises for legal birth control and abortion ${ }^{26}$. She also stated, that the conscious marriage is contrary to the interest of capitalists who need cheap labour force, to realise their financial aims.

Paradoxically, Helen Keller herself, would always dun for the role of a woman, trying to repeal the stereotypical ways of perceiving her as a person, due to her disability - both as the role of her conquering her own fate, as well as, her as a poor pitiful cripple. Unfortunately she failed to overcome the image of a person with disability as an asexual, eternal child. In 1916, during Anne Sulli-

${ }^{23}$ H. Keller, Letter To An English Woman-Suffragist, <https://www.disability museum.org/dhm/lib/detail.html?id=2499> [29.05.2019].

${ }^{24}$ H. Keller, You Inspire Other Woman, [in:] Helen Keller: Selected..., op. cit., p. 221.

${ }^{25}$ Margaret Sanger - an American feminist, and an activist for conscious motherhood, the founder of the American Birth Control League.

26 Battling the Powers of Darkness-Helen Keller, Margaret Sanger and Birth Control, <https://www.nyu.edu/projects/sanger/articles/keller.php> [29.05.2019]. 
van's conditions, the duties of Keller's secretary ware taken over by Peter Fagan. Affection arises between them. When their relation, and marriage plans saw the light of day, Keller's family strongly opposed their relationship. Under their influence, Keller accepts the fact that marriage and motherhood, can never happen to a deafblind woman ${ }^{27}$. Peter Fagan is gone from her life forever. "How alone and unprepared I often feel, especially when I wake at night" 28 - Keller wrote in a letter to Sullivan on 30 January 1917, right after Fagan left.

\section{Keller against the war}

Keller wrote: "I believe women would use the ballot to prevent war and destroy the ideas that make war possible" 29 . Since the beginnings of her activity she was an opponent of war, considering it to be a profit-driven effort. She publicly criticised the United States' accession to both World War I and World War II.

10 May 1933, when in twenty largest cities of the Third Reich, including Berlin, Munich, Dresden and Frankfurt, forbidden books are being burnt at stakes, the Keller's essay titled "How I Became a Socialist" is also burning. Keller is furious, and writes a letter, that, in its initial version was addressed to Hitler himself: "History has taught you nothing if you think you can kill ideas. Tyrants have tried to do that often before and the ideas have risen up in their might and destroyed them. You can burn my books and the books of the best minds in Europe, but the ideas in them have seeped through a million channels, and will continue to quicken other minds" 30 .

27 K.E. Nielsen, Introduction to Helen Keller's letter How Alone and Unprepared I Often Feel, [in:] Helen Keller: Selected..., op. cit., p. 96.

${ }^{28}$ H. Keller, The Enfranchisement of Woman, [in:] ibidem, p. 96.

${ }^{29}$ H. Keller, Why Men Need Woman Suffrage, <https://www.disabilitymuseum. org $/$ dhm/lib/detail.html?id=2670\&page=2> [29.05.2019].

${ }^{30} \mathrm{H}$. Keller, Letter from Helen Keller to Adolf Hitler/German students expressing anger over Hitler's policies, <https:/ / www.afb.org/HelenKellerArchive?a=d\&d=A-HK 02-B210-F03-001.1.1> [29.05.2019]. 
In this very letter, she decisively defends the Jews: "Do not imagine your barbarities to the Jews are unknown here. God sleepeth not, and He will visit His Judgement upon you"31. Keller assumed, that her duty is to direct the attention of the Americans to the dramatic situation of the Jews that inhabit the Nazi-occupied countries. In 1938, she persuaded the publisher of The New York Times, John H. Finley, to publish a letter regarding the tragic fate of this nation, and of the persons with disabilities in the Nazi Germany. In a letter regarding the shutting down the Israelite Institute for the Blind in Vienna, she writes as follows: "The other day i received a letter which, like concentrated fire, burnt deeper into my consciousness (...) it brought the sense of a nameless shadow worse than blindness..." 32 .

After the end of World War II, Helen Keller travels to Japan, after 11 years she once again visits Hiroshima and Nagasaki. She experiences a sight that is difficult to describe with words. Nielsen notes - "The human misery was more than she knew how to communicate" 33 . Keller notes "As a result of that inferno two hundred thousand persons are now dead, and the suffering caused by atomic burns and other wounds is incalculable". In Hiroshima, she touches a burnt face of a Japanese officer: "He let me touch his face, and the rest is silence $34^{\prime \prime}$ - she writes.

\section{Conclusion}

Helen Kellers story does not begin, and does not end at the moment, where a little girl miraculously comprehends the mystery

\footnotetext{
31 Ibidem, [29.05.2019].

32 H. Keller, The Nazi Authorities Have Closed The Institute, [in:] Helen Keller: Selected..., op. cit., p. 199.

${ }^{33}$ K.E. Nielsen, The Radical..., op. cit., p. 92.

${ }^{34}$ Keller's quotes come from the monograph: K.E. Nielsen, The Radical..., op. cit., p. 92.
} 
of language, in a well-house in Tuscambia. Despite the fact, that the most known film dedicated to Keller titled "The Miracle Worker", depicts her as a child, she lived for almost 88 years (born on 27 June 1880, died on 1 June 1968), having a more varied and complicated life than anyone in the history of the United States. She was a socialist, a member of the American Civil Liberties Union (ACLU) ${ }^{35}$, a radical critic of the war, and a feminist. Recalling Keller's life as but a sad and bland story, abolishes her accomplishments - her activity, her opinions, and her political views ${ }^{36}$. Kim E. Nielsen recalls a view, that persons such as Keller can be an inspiration to others, only when we avoid controversy and create unidimensional characters, to present their story. The author notes, that the view is completely false. One must acknowledge that memorising the historical characters by sanctifying them is falsifying history. Helen Keller was a complicated person, leading a very complicated life ${ }^{37}$. Katarzyna Ojrzyńska notes that "(...) Instead of a mirror, persons with disabilities were given a few trite portraits"38. Reclaiming this or other stories of persons with disabilities is like the society looking into the mirror of history, that up until now, could only be created by its able-bodied and privileged part. It allows to regain the areas lost "for the excluded community of persons with disabilities, still perceived as deviation, rather than diversity" 39 .

\section{Bibliography}

[1] Battling the Powers of Darkness-Helen Keller, Margaret Sanger and Birth Control, https://www.nyu.edu/projects/sanger/articles/keller.php.

[2] Crow L., Helen Keller: Rethinking the Problematic Icon, "Disability \& Society" 2000 o 6(15), DOI: 10.1080/713662010.

${ }^{35}$ American Civil Liberties Union (ACLU) - an American non-profit organisation, for the protection of the civil rights guaranteed by the constitution. Founded in 1920.

${ }^{36}$ K.E. Nielsen, The Radical..., op. cit., p. 141.

37 Ibidem, p. 142.

38 K. Ojrzyńska, Nabila Shabana..., op. cit., p. 174.

${ }^{39}$ Ibidem, p. 174. 
[3] Garland-Thomson R., Feminist Disability Studies, "Signs" 2005 no 30(2), DOI: $10.1086 / 423352$.

[4] Keller H., The Modern Woman, <https://www.disabilitymuseum.org/dhm/ lib/detail.html?id=2449>.

[5] Keller H., Why Men Need Woman Suffrage, <https://www.disabilitymuseum. org/dhm/lib/detail.html?id=2670\&page $=2>$.

[6] Keller H., Historia mojego życia, Czytelnik, Warszawa 1978.

[7] Keller H., I Am For You, [in]: Helen Keller. Selected writing, (ed.) K.E. Nielsen, New York University Press, New York - London 2005.

[8] Keller H., Letter from Helen Keller to Adolf Hitler/German students expressing anger over Hitler's policies, <https://www.afb.org/HelenKellerArchive?a=d\&d=A-H K02-B210-F03-001.1.1>.

[9] Keller H., Letter To An English Woman-Suffragist, <https://www.disabilitymu seum.org/dhm/lib/detail.html?id=2499>.

[10] Keller H., The Enfranchisement of Woman, [in:] Helen Keller: Selected writing, (ed.) K.E. Nielsen, New York University Press, New York - London 2005.

[11] Keller H., The Nazi Authorities Have Closed The Institute, [in:] Helen Keller: Selected writing, (ed.) K.E. Nielsen, New York University Press, New York - London 2005.

[12] Keller H., What The Blind Can Do, <https://www.disabilitymuseum.org/dhm/ lib/detail.html?id=2502\&page $=2>$.

[13] Keller H., You Inspire Other Woman, [in:] Helen Keller: Selected writing, (ed.) K.E. Nielsen, New York University Press, New York - London 2005.

[14] Nielsen K.E., Helen Keller and the Politics of Civic Fitness, [in:] The New Disability History: American Perspectives, (eds.) P.K. Longmore, L. Umansky, New York University Press, New York - London 2001.

[15] Nielsen K.E. (ed.), Helen Keller: Selected writing, New York University Press, New York - London 2005.

[16] Nielsen K.E., The Radical Lives of Helen Keller, New York University Press, New York and London 2009.

[17] Ojrzyńska K., Nabila Shabana dialog z kultura sprawna, „Tekstualia” 2017 no 4 (51).

[18] Ojrzyńska K., O leczeniu społecznej amnezji: Akcja T4 w kulturze wspótczesnej, [in:] Niepetnosprawność w teatrze i performansie, (ed.) E. Godlewska-Byliniak, Fundacja Teatr 21, Warszawa 2018.

[19] Shaban N., Body Fascism and Genetic Cleansing (a television polemical script by Nabil Shaban), <http://www.geocities.ws/jinghiz/genetic_cleansing.html>

[20] <https://www.disabilitymuseum.org> [29.05.2019]

[21] <https://www.afb.org> [29.05.2019]

[22] <https://www.nyu.edu> [29.05.2019]

[23] <http://www.geocities.ws/jinghiz/genetic_cleansing.html> [29.05.2019] 